\title{
Changes in alpine plant growth under future climate conditions
}

\author{
A. Rammig ${ }^{1}$, T. Jonas ${ }^{2}$, N. E. Zimmermann ${ }^{3}$, and C. Rixen ${ }^{2}$ \\ ${ }^{1}$ Earth System Analysis, Potsdam Institute for Climate Impact Research, Telegraphenberg A62, 14412 Potsdam, Germany \\ ${ }^{2}$ WSL Institute for Snow and Avalanche Research SLF, Flüelastr. 11, 7260 Davos Dorf, Switzerland \\ ${ }^{3}$ WSL Institute for Forest Snow and Landscape Research, Zürcherstr. 111, 8903 Birmensdorf, Switzerland
}

Received: 2 September 2009 - Published in Biogeosciences Discuss.: 18 November 2009

Revised: 23 April 2010 - Accepted: 30 May 2010 - Published: 24 June 2010

\begin{abstract}
Alpine shrub- and grasslands are shaped by extreme climatic conditions such as a long-lasting snow cover and a short vegetation period. Such ecosystems are expected to be highly sensitive to global environmental change. Prolonged growing seasons and shifts in temperature and precipitation are likely to affect plant phenology and growth. In a unique experiment, climatology and plant growth was monitored for almost a decade at 17 snow meteorological stations in different alpine regions along the Swiss Alps. Regression analyses revealed highly significant correlations between mean air temperature in May/June and snow melt out, onset of plant growth, and plant height. These correlations were used to project plant growth phenology for future climate conditions based on the gridded output of a set of regional climate models runs. Melt out and onset of growth were projected to occur on average 17 days earlier by the end of the century than in the control period from 1971-2000 under the future climate conditions of the low resolution climate model ensemble. Plant height and biomass production were expected to increase by $77 \%$ and $45 \%$, respectively. The earlier melt out and onset of growth will probably cause a considerable shift towards higher growing plants and thus increased biomass. Our results represent the first quantitative and spatially explicit estimates of climate change impacts on future growing season length and the respective productivity of alpine plant communities in the Swiss Alps.
\end{abstract}

Correspondence to: A. Rammig (anja.rammig@pik-potsdam.de)

\section{Introduction}

The global temperature is increasing and in Earth's alpine regions signs of climate change can already be observed visually by the impressive melting of the alpine glaciers (e.g. Oerlemans, 2005) or upward migration of plant species (Grabherr et al., 1994). Data indicate that especially in high altitude and latitude regions the climate is changing more rapidly than elsewhere (IPCC, 2007; Arctic Climate Impact Assessment - ACIA, 2004). In the Alps, mean snow depth, the duration of continuous snow cover and the number of snowfall days at mid and low elevations have decreased since the 1980s (Laternser and Schneebeli, 2003; Marty, 2008), and the decrease can be attributed to rising temperatures (Scherrer et al., 2004).

Modelling of future climate in the Alps is hampered by the complex alpine topography. Nevertheless, current climate models agree in expecting increased temperatures in all seasons by 2050. Regional climate scenarios for the Swiss Alps are discussed in detail in the OcCC report (OcCC Konsortium, 2007). According to these scenarios, a temperature increase of $3{ }^{\circ} \mathrm{C}$ in summer and $2{ }^{\circ} \mathrm{C}$ in fall, winter, and spring may be expected. Summer precipitation is expected to decrease by $20 \%$ and winter precipitation to increase by $10 \%$. The combined effects of the snow line rising in altitude due to increased temperature and the changes in temperature-precipitation patterns are expected to result in increasing amounts of snow in midwinter only above $2000 \mathrm{~m}$ a.s.l. (Abegg et al., 2007; OcCC Konsortium, 2007). At the same time warmer temperatures will also accelerate

Published by Copernicus Publications on behalf of the European Geosciences Union. 
snow depletion, and thus increasing peak snow depth will not necessarily translate into later melt out. On the contrary, several snow climatological studies predict significantly earlier melt out (Beniston et al., 2003; Jasper et al., 2004; Keller et al., 2000; Laternser and Schneebeli, 2003; Scherrer et al., 2004). Also studies using distributed snow cover models project melt out to be preponed by several weeks within the next century (Bavay et al., 2009; Magnusson et al., 2009). As a direct effect of those snow cover changes, the timing of the growing season will be altered.

Alpine vegetation has already responded to the changing environmental conditions: Alpine plant species have been migrating upward (e.g. Grabherr et al., 1994; Walther et al., 2005; Sanz-Elorza et al., 2003), the tree line has expanded to higher elevations (Camarero and Gutiérrez, 2004; Gehrig-Fasel et al., 2007; Kullman, 2002; Mindas et al., 2000; Penuelas and Boada, 2003; Sanz-Elorza et al., 2003; Shiyatov et al., 2007), while in the Arctic, shrub cover has become denser and higher (Sturm et al., 2001; Tape et al., 2006). A first step in investigating phenology and growth pattern of alpine plants consists in analyzing long-term monitoring data. Keller et al. (2000) analysed a 70 year-dataset from permanent vegetation plots at high elevations. They found an earlier onset of growth due to shorter winter periods. However, their study was only based on one site in Switzerland. Other long term monitoring investigations in Switzerland (e.g. Swiss phenological "Spring plant" time series, 1702-2007) were used to estimate changes in phenology and to develop phenological models, however these studies were conducted at elevations below $800 \mathrm{~m}$ a.s.l. (Rutishauser et al., 2008; Schleip et al., 2008a, b). Manipulation experiments showed a strong response of flowering phenology to earlier snow-melt in subalpine and alpine ecosystems (Dunne et al., 2003; Rixen et al., 2010; Wipf et al., 2006).

To our knowledge, so far no models have attempted to quantify the expected changes in snow melt timing on plant growth and phenology in alpine and subalpine areas. Shifting phenology of various plant species was projected often using the relation between air temperature and spring phenology, but not for the Alps (e.g. Menzel et al., 2006; Schleip et al., 2008a; Sparks et al., 2000). Species distribution model are applied in studies on shifts in species ranges in alpine regions (e.g. Brooker et al., 2007; Guisan and Theurillat, 2000; Guisan et al., 1998; Theurillat and Guisan, 2001). These models are often applied to large regions and can be used to estimate potential changes in species distribution and diversity depending on environmental factors. They however do not consider transient changes and non-linear effects on vegetation (e.g. discussions in Hickler et al., 2009; Rickebusch et al., 2008; Thuiller et al., 2008). Such dynamics are incorporated in dynamic vegetation models, which are in many studies applied to forests in mountain regions (e.g. Fischlin and Gyalistras, 1997b; Lischke et al., 1998) but not to areas above tree line. However, variables resulting from complex interactions of factors, such as timing of plant growth may currently be better addressed with simple but straightforward modelling approaches.

In the present study, we make use of a unique data set from a Swiss network of automated snow measuring stations distributed over the central part of the Alps (Jonas et al., 2008). Their study has determined snow-climatologic predictors for plant height and growth rates for vegetation at these sites using path analysis. However, their predictors constitute complex interactions between melt out, temperature and precipitation, which today are hardly predictable from general circulation model (GCMs) or regional climate model (RCM) data. To overcome this problem, here we re-analysed the data set for correlation between plant growth data and climate indices which are well represented by today's climate models. Ultimately, we used correlations between melt out (M), growth onset $(\mathrm{G})$ and plant height $(\mathrm{P})$ and mean temperatures of May and June to project effects of climate change into the future. In particular, we asked the following questions: How much earlier can melt out be expected in the Swiss Alps in a changing climate? How may future climate changes influence the timing of growth and productivity in Alpine plant communities?

\section{Materials and methods}

\subsection{Study sites and IMIS station data}

The WSL Institute for Snow and Avalanche Research SLF established a meteorological network of over 100 stations that have monitored snow and weather data since 1996 (Rhyner et al., 2002). Each meteorological station records among others data of temperature, wind speed and snow depth. Snow depth is measured using an ultrasonic snow depth sensor (SR50, Campbell Scientific, USA). During summer, these sensors can also track vegetation height (Fig. 1a). The quality of these measurements is documented in Jonas et al. (2008). From the existing stations, 17 sites were identified that reflect subalpine and alpine grasslands with a homogeneous vegetation of at least $10 \mathrm{~cm}$ height at full growth (Fig. 1b). For these sites, monitoring data were available for the period between 1997 and 2005 (in the following denoted as "current period"). All sites were open, flat, and generally not exposed to wind and ranged from 1560 to $2545 \mathrm{~m}$ a.s.l. Most of the sites are moderately grazed by cattle, which is the dominant type of land-use in the Swiss Alps at these elevations. Therefore, the sites were dominated by grass and herb species characteristic of plant communities from alpine pastures and meadows.

From the 17 climate stations described above, we used daily temperature data to derive monthly means. Measured phenological data (i.e. melt out, growth onset, and maximum plant height, denoted in the following as "plant height"; Fig. 1a) were selected as response variables for regression analysis. This data set comprised 82 data points 


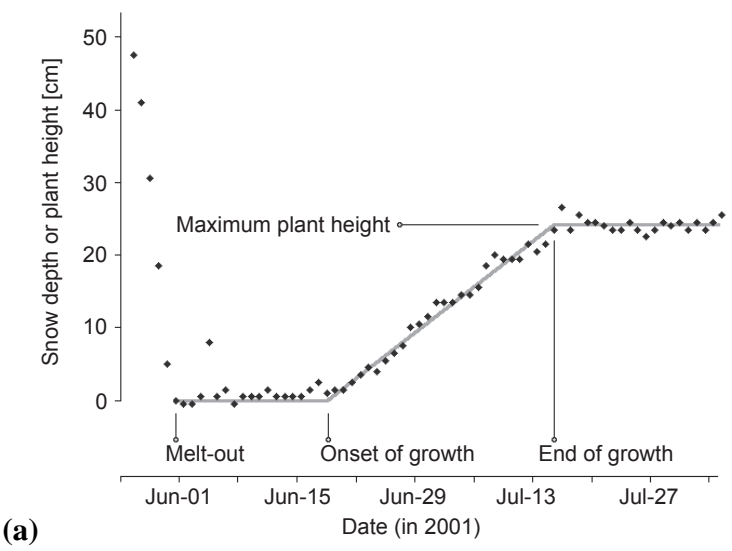

(b)

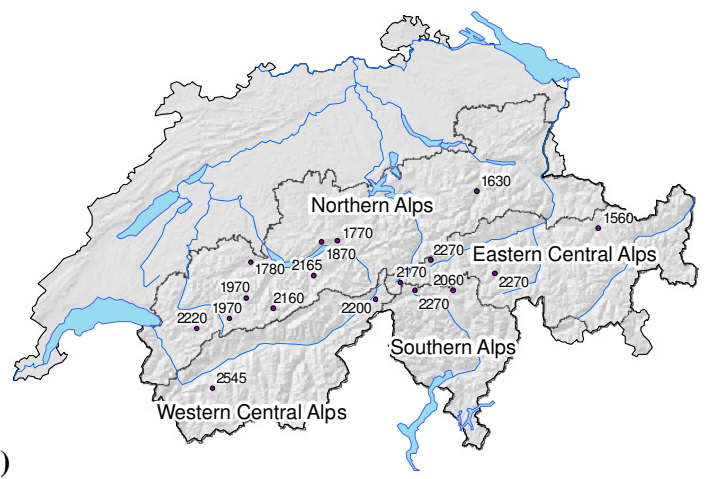

Fig. 1. (a) The ultrasonic snow depth sensor tracks vegetation height during summer (black dots) here shown for the site Tujetsch (2270 m a.s.1.). From these measurements, melt out, onset of growth and maximum plant height (denoted as "plant height" throughout the text) can be determined. (b) Map of Switzerland and the locations of the IMIS snow stations with elevation and the four selected biogeographic regions for the simulations with high resolution climate data (figures modified from Jonas et al., 2008).

from different stations and years (for details see Jonas et al., 2008). Plant height correlated significantly with aboveground standing biomass (dry matter harvested at specific dates of the year before the onset of grazing) as determined from measurements $\left(R^{2}=0.89\right.$; Jonas et al., 2008). Therefore, we calculated above-ground biomass AGB $\left(\mathrm{g} \mathrm{m}^{-2}\right)$ as

$\mathrm{AGB}=194 \cdot \ln (P)-306.94$

where $P$ is the maximum plant height $(\mathrm{cm})$. As our data were derived from meadow and pasture vegetation in relatively flat terrain, our predictions can naturally only be valid for related vegetation types and not for forests or shrubland.

\subsection{Climate scenarios}

Below we describe the two different climate data sets used in our study. The "low resolution climate scenarios" comprise an ensemble of two climate models forced with different $\mathrm{CO}_{2}$-emission scenarios at a resolution of approximately $16 \mathrm{~km}$. The $1 \mathrm{~km}$ "high resolution climate scenario" was created for one climate model forced with one emission scenario.

\subsubsection{Low resolution climate scenarios}

For the future projections, we used gridded data of mean monthly temperature for Switzerland, which were extracted from a dataset for Europe at $10 \times 10 \mathrm{~min}$ spatial resolution ( $\sim 16 \mathrm{~km}$ ) from 1901-2100 (Mitchell et al., 2004; New et al., 2000). Mitchell et al. (2004) constructed the historical data for the period from 1901 to 2000 from interpolated observations over Europe. They derived future projections for 2001 to 2100 from simulations by two Atmosphere-Ocean coupled Global Circulation Models (AOGCMs). Mitchell et al. (2004) superimposed the AOGCM-derived climate anomalies onto their interpolated observation data, implying that present-day biases in the AOGCM simulation were removed (for details see Mitchell et al., 2004; Hickler et al., 2009). The two AOGCMs applied for these projections were the Hadley Centre model HadCM3 (Gordon et al., 2000) and NCAR-PCM (Washington et al., 2000). The HadCM3 model, which projects a rather "warm and dry" climate, was forced with the Special Report on Emission Scenarios (SRES) A1FI, A2 and B1 emission scenarios, while the NCAR-PCM, which projects rather "cool and wet" climate, was forced only with the SRES-A2 scenario (Nakicenovic et al., 2000). The SRES-A1FI scenario projects higher carbon emissions than $\mathrm{A} 2$ and $\mathrm{B} 1$, and thus leads to a stronger increase in temperature. The four climate projections (HadCM3-A2, HadCM3-A1FI, HadCM3-B1, NCARPCM-A2) applied in this study nevertheless only span a part of the uncertainty range (Fronzek and Jylhä, 2009). In order to estimate how good the above described climate data represent our measurements for the current period (1997-2005), we compared the measured and simulated May/June average temperatures for the overlapping period from 1997 to 2000 . The comparison was done for each site and each year. An offset correction for the temperature of the grid cell was calculated by comparing the altitude of the climate station and the grid cell using a lapse rate for temperature of $0.6^{\circ} \mathrm{C}$ per $100 \mathrm{~m}$ of altitude.

\subsubsection{High resolution climate scenario}

High resolution climate maps were prepared at a $1 \mathrm{~km}$ spatial resolution. To do so we first aggregated the available base maps of 30-year average monthly temperature of May and June for the period of 1961-1990 (in the following denoted as "reference period") from a $25 \mathrm{~m}$ temperature map. This map was derived by spatially interpolating standardized 
30-year monthly temperatures from ca. 180 climate stations of the Swiss Meteorological network using thin plate splines (Franke, 1982; see Zimmermann and Kienast, 1999 for details). In a next step, the low resolution climate change scenario from 1901-2100 was scaled to $1 \mathrm{~km}$ resolution. Due to computational limitations at the time of the project, the high resolution climate projection was only computed for the HadCM3-A2 scenario. To do so, we first generated monthly climate anomalies compared to the $1 \mathrm{~km}$ reference climate at the low resolution (10'). Anomalies represent the amount of projected temperature deviation compared to the same month of the reference period. These anomalies were then spatially interpolated using inverse distance weighted interpolations (IDW, Shepard, 1968) to a $1 \mathrm{~km}$ spatial resolution and added to the reference climate. This procedure is similar to the one used by Fischlin and Gyalistras (1997a).

\subsection{Statistical models for melt out, onset of growth and plant height: today and future projections}

\subsubsection{Regression models}

Linear regression analysis was used to determine one simple but robust predictor for melt out $(\mathrm{M})$, growth onset $(\mathrm{G})$ and maximum plant height $(\mathrm{P})$ under current climate conditions (1997-2005). By means of systematic data exploration we determined the mean May/June temperature to constitute the best predictor, as it yielded the best combination of (1) "correlation strength": May/June temperature was among the variables that showed the strongest correlation to melt out, growth onset and plant height, (2) "simplicity": temperature is a direct output variable of climate models and probably the variable that is best understood and can be predicted with the least uncertainty, and (3) "universality": May/June temperature had the highest correlations among all predictors if a single predictor was sought for all three response variables at the same time. Accordingly, the three regression models were obtained as follows:

$V_{i}\left(T_{\mathrm{obs}}\right)=a_{i} \cdot T_{\mathrm{obs}}+b_{i}$

$V_{i}$ represents the response variables and was calculated for $V_{\mathrm{M}}$ (melt out; day of year), $V_{\mathrm{G}}$ (onset of growth; day of year) and $V_{\mathrm{P}}$ (plant height in $\mathrm{cm}$ ), $a$ and $b$ are the best-fit regression coefficients, and $T_{\mathrm{obs}}$ is the observed May/June-mean temperature at our sites.

The capability of the regression models (in the following denoted as "simulations") to predict $V_{\mathrm{M}}, V_{\mathrm{G}}$ and $V_{\mathrm{P}}$ from the May/June-mean temperature of the 10' grid cells was analysed for each observed site and each year for the current period 1997-2005 using the HadCM3-A1FI climate data $\left(T_{\text {cur }}\right)$. The HadCM3-A1FI scenario was chosen arbitrarily, the temperature trajectories of the four climate scenarios did not differ much during the first five years of the projection (2000-2005). $V_{\mathrm{M}}, V_{\mathrm{G}}$ and $V_{\mathrm{P}}$ as predicted from $T_{\text {cur }}$ with Eq. (2) was compared to the observed phenology variables from 1997-2005. Note, that $T_{\text {cur }}$ was corrected for potential differences in elevation between the sites and their corresponding grid cells by applying a lapse rate of $0.6^{\circ} \mathrm{C}$ per $100 \mathrm{~m}$ of altitude.

\subsubsection{Application}

Next, the regression models were applied to all grid cells in Switzerland above $1500 \mathrm{~m}$ and within the temperature range available from the observed temperature data, in order to not exceed the calculated range of the regression. All grid cells with temperatures outside our regression range (under future conditions) were removed from the calculations, i.e. a gridcell was removed from the analysis if the May/June temperature was $>12.25^{\circ} \mathrm{C} . V_{\mathrm{M}}, V_{\mathrm{G}}$ and $V_{\mathrm{P}}$ were calculated for $T_{\text {sim_low }}$ from Eq. (2), which is the projected May/June temperature of four low resolution climate projections (HadCM3-A2, HadCM3-A1FI, HadCM3-B1, NCARPCM-A2). The simulation results were analysed by contrasting box plot histograms for $V_{\mathrm{M}}, V_{\mathrm{G}}$ and $V_{\mathrm{P}}$ for the "control period" (1971-2000) and three future periods (2001-2030, 2031-2060 and 2061-2090).

In the same way, the regression models were applied to the high resolution climate data. $V_{\mathrm{M}}, V_{\mathrm{G}}$ and $V_{\mathrm{P}}$ were calculated from Eq. (2) for $T_{\text {sim_high }}$. For the analysis, Switzerland was separated into four biogeographic regions, which differ in their climate now and in the projected future: the Northern Alps, the Western Central Alps, the Eastern Central Alps and Southern Alps (Fig. 1b). For the comparison of the four biogeographic regions as shown in Table 1, the temperature data $\left(T_{\text {sim_high }}\right)$ were standardized to $2000 \mathrm{~m}$ for all regions by assuming a lapse rate of $0.6^{\circ} \mathrm{C}$ per $100 \mathrm{~m}$ of altitude. Averages of $V_{\mathrm{M}}, V_{\mathrm{G}}$ and $V_{\mathrm{P}}$ for 1961-1990 (reference period), 2001-2030, 2031-2060 and 2061-2100 were calculated for the analysis of the results.

\section{Results}

\subsection{Data comparison and statistical models}

The measured mean May/June-temperature for all 17 stations for all years from 1997 to 2005 was $7.4 \pm 1.3^{\circ} \mathrm{C}$. The temperature for the corresponding grid cells of the climate models was $7.3 \pm 2.2^{\circ} \mathrm{C}$. Simulated and observed climate data for the period 1997-2005 showed a positive significant relationship for May/June mean temperature (linear regression: $\left.T_{\mathrm{obs}}=0.996 \cdot T_{\text {sim_low }}, R^{2}=0.5, p<0.001, \mathrm{RMSE}=1.4\right)$. Thus we assumed that the low resolution climate data from Mitchell et al. (2004) and Fronzek and Jylhä (2009) represented the temperature at high altitudes in Switzerland well and hence could be used for projections.

Regression analyses were conducted for predicting $V_{M}$ (melt out; day of year), $V_{\mathrm{G}}$ (onset of growth; day of year) and $V_{\mathrm{P}}$ (plant height in $\mathrm{cm}$ ) using $T_{\mathrm{obs}}$, the mean temperature of May and June as measured by the IMIS stations (Fig. 2). 

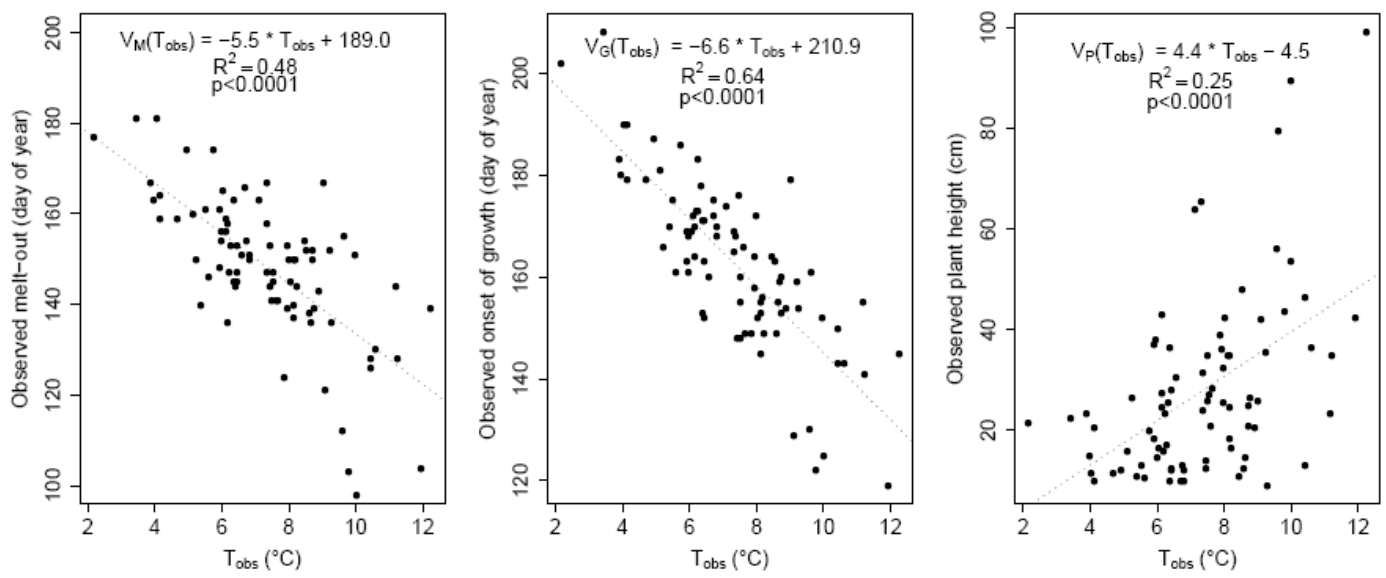

Fig. 2. Regression models for predicting melt out $\left(V_{\mathrm{M}}\right)$, onset of growth $\left(V_{\mathrm{G}}\right)$ and plant height $\left(V_{\mathrm{P}}\right)$ from measured May/June-mean temperature $\left(T_{\mathrm{obs}}\right)$ for the current period 1997-2005.

The analysis resulted in the following three regression models

$V_{\mathrm{M}}\left(T_{\mathrm{obs}}\right)=-5.5 \cdot T_{\mathrm{obs}}+189.0$

$V_{\mathrm{G}}\left(T_{\mathrm{obs}}\right)=-6.6 \cdot T_{\mathrm{obs}}+210.9$

$V_{\mathrm{P}}\left(T_{\mathrm{obs}}\right)=4.4 \cdot T_{\mathrm{obs}}-4.5$

All three models were significant $\left(R^{2}\right.$ for $(2)=0.48, p<0.001$; $R^{2}$ for (3)=0.64, $p<0.001 ; R^{2}$ for (4) $=0.25, p<0.001$, see Fig. 2).

\subsection{Projections of melt out, onset of growth and biomass}

\subsubsection{Melt out}

The mean date of melt out $\left(V_{\mathrm{M}}\right)$ as predicted from $T_{\mathrm{obs}}$ for all stations was 27 May (day of year $148 \pm 15$ days) between 1997 and 2005. $V_{\mathrm{M}}$ predicted from $T_{\mathrm{obs}}$ and $T_{\text {sim_low }}$ corresponded well and had a RMSE of 10.58 (Fig. 3). All projections consistently estimated melt out to occur earlier in the year over the next century. Our simulations for the recent past (1971-2000) estimated mean melt out on 12 June (day of year $163 \pm 9$ days). Due to the standardization method of the climate data as performed by Mitchell et al. (2005; see Methods section), the temperature pathway for the control period (1971-2000) was the same for the four climate scenarios. Under future climate conditions, the projections of melt out differed clearly (Fig. 4), with strongest changes projected by the HadCM3 model forced with the SRES-A1FI CO ${ }_{2}$ trajectory. Melt out was projected to occur by the end of the century at 17 May (mean: day of year $137 \pm 9$ days), which is about 26 days earlier than under current conditions. For the HadCM3-A2 model, $V_{M}$ was projected 18 days earlier (day of year $145 \pm 9$ days), for the HadCM3-B1 two weeks earlier (day of year $149 \pm 9$ days), and for the NCAR-PCM-A2
Table 1. Melt out $\left(V_{\mathrm{M}}\right)$, onset of growth $\left(V_{\mathrm{G}}\right)$ and plant height $\left(V_{\mathrm{P}}\right)$ for the reference and future temperature conditions as projected by the high resolution climate data $\left(T_{\text {sim }}\right.$ high, $1 \mathrm{~km}$ resolution, HadCM3-A2 scenario) for four selected biogeographic regions of the Swiss Alps. Given are the averages over the years 1961-1990 as reference conditions, future projections for 2001-2030, 20312060 and 2061-2100. Standard deviations are given in brackets. For reasons of comparability, the temperature values for each region were standardized to an altitude of $2000 \mathrm{~m}$ a.s.l. by assuming a lapse rate of $0.6^{\circ} \mathrm{C}$ per $100 \mathrm{~m}$ in altidude. Above-ground biomass was calculated from plant height (see methods).

\begin{tabular}{|c|c|c|c|c|}
\hline \multirow[t]{2}{*}{ Region } & \multicolumn{4}{|c|}{ Melt-out (day of year) } \\
\hline & $1961-1990$ & $2001-2030$ & $2031-2060$ & $2061-2100$ \\
\hline Northen Alps & $176(1.5)$ & $172(1.9)$ & $164(2.2)$ & $153(2.3)$ \\
\hline Western Central Alps & $173(1.8)$ & $166(2.0)$ & $157(3.0)$ & $147(2.6)$ \\
\hline Eastern Central Alps & $173(3.0)$ & $167(3.4)$ & $159(3.2)$ & $147(3.9)$ \\
\hline \multirow[t]{3}{*}{ Southern Alps } & $174(2.0)$ & $168(2.3)$ & $159(2.5)$ & $149(2.9)$ \\
\hline & \multicolumn{4}{|c|}{ Onset of growth (day of year) } \\
\hline & $1961-1990$ & $2001-2030$ & $2031-2060$ & $2061-2100$ \\
\hline Norther Alps & $160(1.3)$ & $156(1.6)$ & $149(1.9)$ & $140(1.9)$ \\
\hline Western Central Alps & $157(1.5)$ & $152(1.7)$ & $144(2.5)$ & $135(2.2)$ \\
\hline Eastern Central Alps & $157(2.5)$ & $152(2.9)$ & $145(2.7)$ & $135(3.3)$ \\
\hline \multirow[t]{3}{*}{ Southern Alps } & $158(1.7)$ & $153(1.9)$ & $145(2.1)$ & $137(2.4)$ \\
\hline & \multicolumn{4}{|c|}{ Plant height $(\mathrm{cm})$} \\
\hline & 1961-1990 & $2001-2030$ & $2031-2060$ & $2061-2100$ \\
\hline Northern Alps & 19(1.0) & $22(1.3)$ & $27(1.5)$ & $34(1.5)$ \\
\hline Western Central Alps & $21(1.2)$ & $25(1.3)$ & $31(2.0)$ & $38(1.7)$ \\
\hline Eastern Central Alps & $21(2.0)$ & $25(2.3)$ & $30(2.1)$ & $38(2.6)$ \\
\hline \multirow[t]{3}{*}{ Southern Alps } & $20(1.3)$ & $24(1.5)$ & $30(1.7)$ & $37(1.9)$ \\
\hline & \multicolumn{4}{|c|}{ Biomass $\left(\mathrm{g} \mathrm{m}^{-2}\right)$} \\
\hline & $1961-1990$ & 2001-2030 & $2031-2060$ & $2061-2100$ \\
\hline Nothern Alps & 259.8 & 290.9 & 333.6 & 378.1 \\
\hline Western Central Alps & 284.9 & 319.5 & 361.3 & 399.0 \\
\hline Eastern Central Alps & 282.6 & 315.4 & 354.9 & 399.8 \\
\hline Southern Alps & 278.0 & 310.2 & 353.3 & 393.4 \\
\hline
\end{tabular}



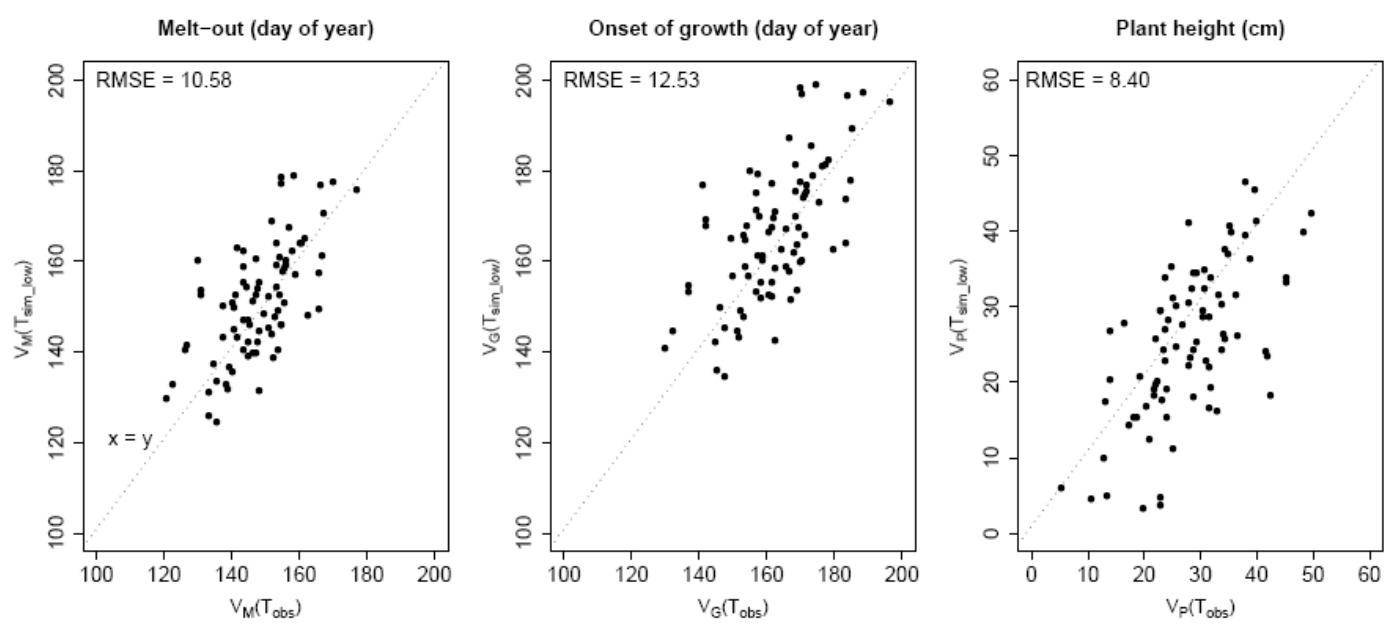

Fig. 3. Comparison of melt out, onset of growth and plant height as predicted from measured May/June-mean temperature $\left(T_{\mathrm{obs}}\right)$ and the low resolution climate data $\left(T_{\text {sim_low }}\right)$ for the current period 1997-2005.

one week (day of year $157 \pm 9$ days) earlier by the end of the century compared to the 1971-2000 control period.

Melt out projections from high resolution HadCM3-A2 temperature $\left(T_{\text {sim_high }}\right)$ were generally similar to the low resolution climate data. Earlier melt out is particularly displayed at the northern and southern edge of the Alps, and within valleys (Fig. 5). In the four regions of Switzerland, the projected melt out standardized for $2000 \mathrm{~m}$ altitude showed small differences: in the Northern Alps, melt out occurred two days later than in Southern Alps and three days later than in the Eastern and Western central Alps under current climate conditions (Table 1). These differences increased under projected future climate, with melt out occurring first in the Western and Eastern central Alps at day 147, two days later in the southern Alps and six days later in the North (Table 1).

\subsubsection{Onset of growth}

The onset of growth $\left(V_{\mathrm{G}}\right)$ was strongly related to melt out and followed at the measured sites about two weeks after melt out (c.f. Jonas et al., 2008), at approximately 11 June (day of year $163 \pm 16$ days). $\mathrm{V}_{\mathrm{G}}$ for $T_{\mathrm{obs}}$ and $T_{\text {sim_low }}$ for the current period 1997-2005 corresponded well (RMSE=12.53; Fig. 3). Generally, the projections from $T_{\text {sim_low }}$ estimated $V_{\mathrm{G}}$ to occur earlier in the year (Fig. 4). For the simulated control period from 1971-2000, the model predicted $V_{\mathrm{G}}$ to take place at about 29 June (day of year $180 \pm 10$ days). Under future climate conditions, simulated $V_{\mathrm{G}}$ was one month earlier under the HadCM3-A1FI scenario (day of year 149 \pm 10 days), 21 days earlier under the HadCM3-A2 scenario (day of year $159 \pm 10$ days), and one week earlier under the NCAR-PCMA2 scenario (day of year $173 \pm 10$ days) for all of Switzerland (Fig. 4). Onset of growth as projected from the high resolution temperature data differed about one week between the investigated regions in Switzerland. $V_{\mathrm{G}}$ was calculated to start earliest in the Western and Eastern Central Alps on $\sim 18$ June, followed by Southern Alps one day later and $\sim 3$ days later in the Northern Alps (Table 1).

\subsubsection{Plant height}

Mean plant height $\left(V_{\mathrm{P}}\right)$ across all sites and years was $27.9 \pm 17.8 \mathrm{~cm}$. Mean $V_{\mathrm{P}}$ corresponded to a biomass production of $339 \pm 252 \mathrm{~g} \mathrm{~m}^{-2}$. For the current period 1997-2005 $V_{\mathrm{P}}$, from $T_{\mathrm{obs}}$ and from $T_{\mathrm{sim} \_ \text {low }}$ were in good agreement for each site and each year (RMSE=8.40; Fig. 3). Under the control climate (1971-2000), the model predicted a plant height of $16.2 \pm 7.0 \mathrm{~cm}$ (estimated biomass: $233 \mathrm{~g} \mathrm{~m}^{-2}$ ). By the end of the century, plant height increased to $36.2 \mathrm{~cm}$ (i.e. a factor of two; estimated biomass: $389 \mathrm{~g} \mathrm{~m}^{-2}$ ) in the warm HadCM3-A1FI climate scenario, and to $21.2 \mathrm{~cm}$ (estimated biomass: $286 \mathrm{~g} \mathrm{~m}^{-2}$ ) in the cooler NCAR-PCM-A2 scenario. Plant height was projected to increase from $\sim 20 \mathrm{~cm}$ to up to $38 \mathrm{~cm}$ until the end of the century (biomass: $400 \mathrm{~g} \mathrm{~m}^{-2}$; Table 1, Fig. 5).

\section{Discussion}

The presented study estimated potential changes in melt out, onset of growth and plant height/biomass under future climate conditions based on a set of measured data in combination with climate scenarios. Our results showed significantly earlier melt out and start of the vegetation period and increased plant growth depending on the climate scenarios. 


\subsection{Impacts of climate change on alpine vegetation}

\subsubsection{Timing of melt out and onset of the vegetation period}

Changes in the timing of melt out are generally determined by a complex interaction of temperature and precipitation: According to climate scenarios of the OcCCConsortium (2007) winter precipitation will increase by $10 \%$. This may only lead to higher amounts of snow in mid winter above $2000 \mathrm{~m}$ altitude (Abegg et al., 2007; OcCC Konsortium, 2007). However, due to projected warmer temperatures and thus accelerated snow melt, increasing peak snow depth are not necessarily leading to a shift to later melt out. The mechanism of warmer temperatures leading to earlier melt out was observed at mid and high elevation ranges during the last decades (Beniston, 2006; Laternser and Schneebeli, 2003; Scherrer et al., 2004). Also recent alpine surface model simulations for river catchments at varying altitudes in the Alps showed 3 to 5 weeks earlier melt out (for the SRES-A2 and B, respectively) by the end of the century (Bavay et al., 2009; Magnusson et al., 2009). Our projections of earlier melt out from May/June temperature correspond with these findings.

Earlier melt out will probably affect alpine vegetation in many ways. Earlier melt out results in a prolonged vegetation period, and thus, potentially higher productivity (see section "Plant growth"). However, several non-linear effects may modify snow-melt effects on vegetation: The snow cover shields the plants from low temperatures by keeping the temperature at a constant level during the winter (e.g. Jones et al., 2001). Thus, if the snow cover is disappearing earlier but frost risk remains constant, which may be expected in a future climate, plants may suffer from freezing damage in early spring frosts (Inouye, 2000). Also elevated $\mathrm{CO}_{2}$ in the atmosphere and warmer temperatures may change the freezing sensitivity of plants (Martin et al., 2010). Therefore, the view that earlier melt out may only come with the beneficial effects of a prolonged vegetation period may be overly simplistic. Our study shows that melt out and the onset of growth may occur up to three weeks earlier, leading to the conclusion that changes in vegetation phenology, and likely also changes in vegetation productivity and composition, will be substantial. An enhanced green-up has already been observed with remote sensing techniques in the Arctic (Myneni et al., 1997) but not yet in the Alps, probably because of methodological problems due to the topography of the Alps (Fontana et al., 2008).

\subsubsection{Plant growth}

Our results suggest that alpine ecosystems will respond to a prolonged growing season with considerably increased plant growth, which is in line with earlier studies on cold-limited ecosystems (Euskirchen et al., 2006; Myneni et al., 1997).
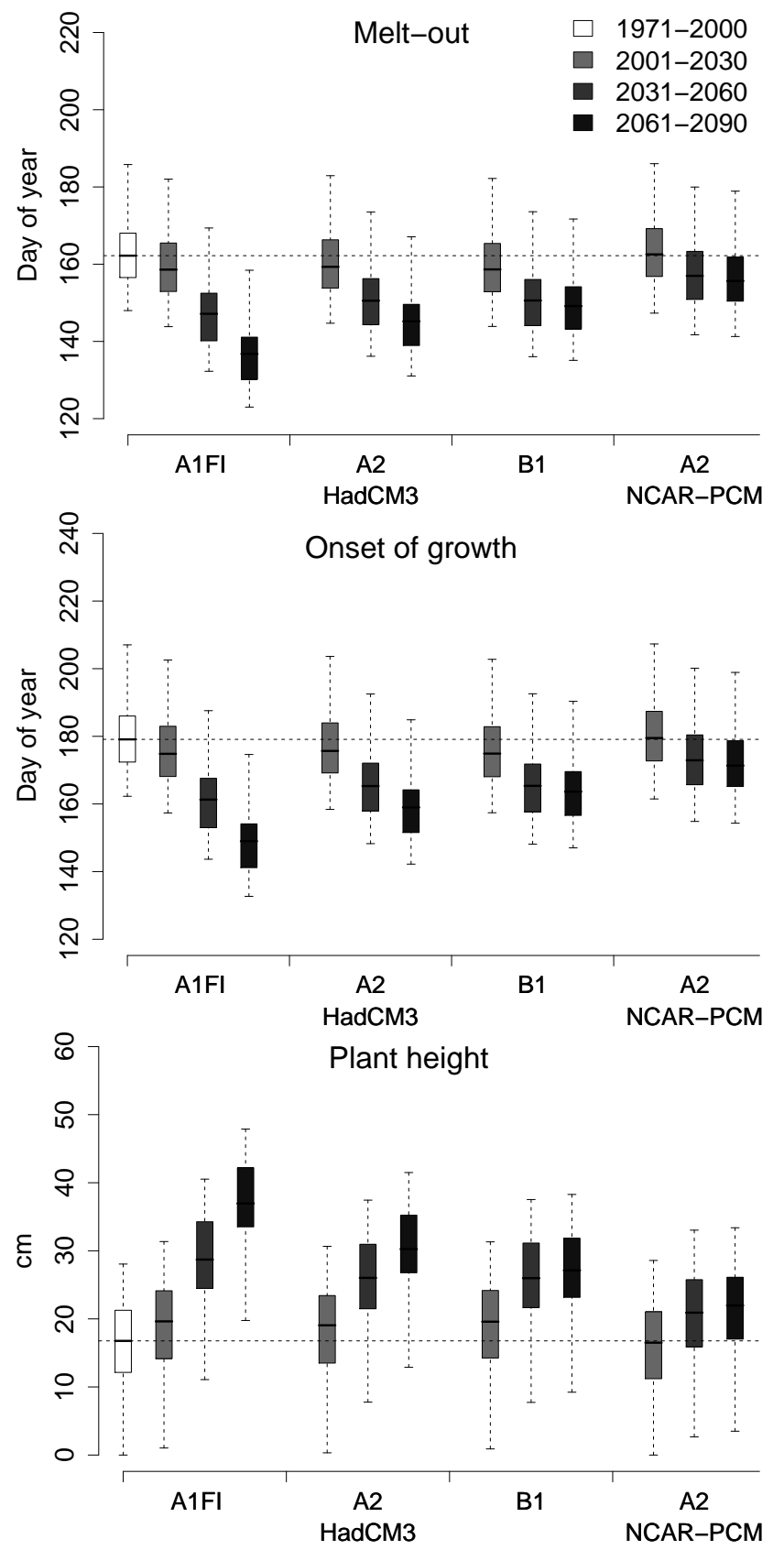

Fig. 4. Melt out $\left(V_{\mathrm{M}}\right)$, onset of growth $\left(V_{\mathrm{G}}\right)$, and plant height $\left(V_{\mathrm{P}}\right)$ as projected from mean May/June temperatures from low resolution climate model ensemble $\left(T_{\text {sim_low }}\right)$. The box plots show the range of data for the specified period. The black line within the box denotes the median, the box gives the upper and lower quartile, which contains $50 \%$ of the data and the whiskers give the minimum and maximum of the data. Note that only gridcells with an altitude $>1500 \mathrm{~m}$ and within the observed temperature range were included in the figure. 

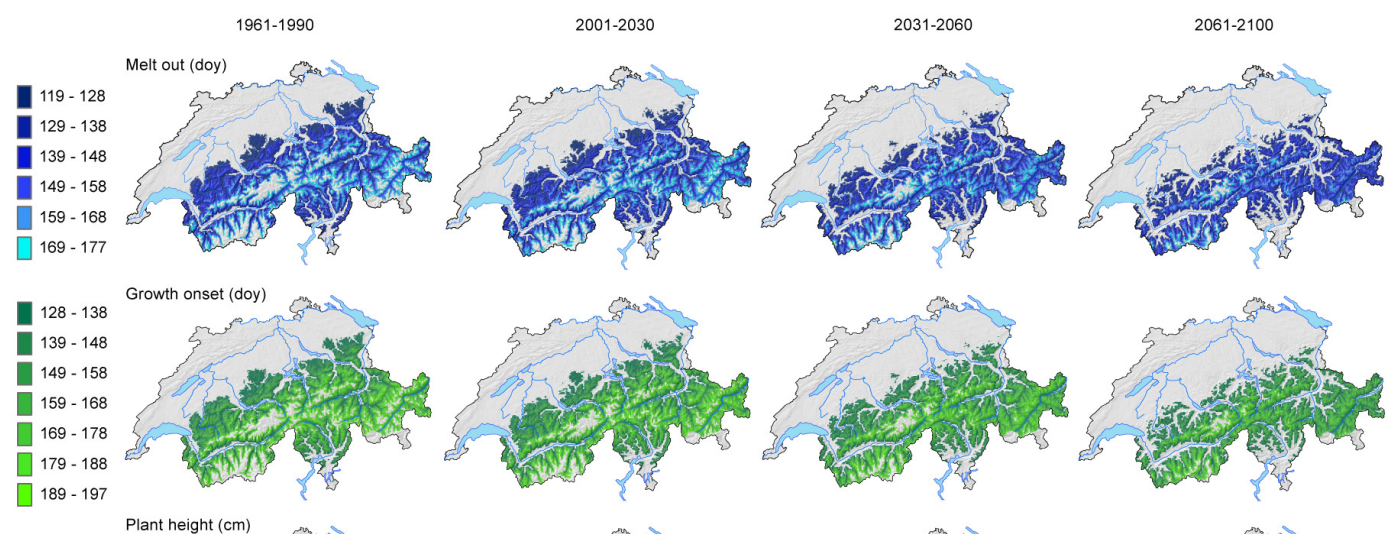

$45-51$
$37-44$
$29-36$
$21-28$
$13-20$
$\square-12$
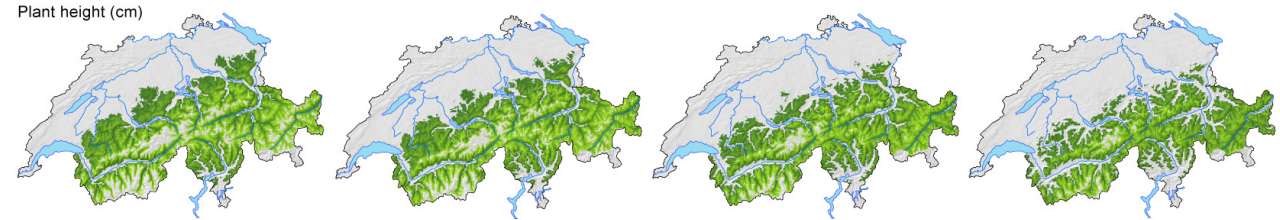

Fig. 5. Regional differences in melt out $\left(V_{\mathrm{M}}\right)$, onset of growth $\left(V_{\mathrm{G}}\right)$, and plant height $\left(V_{\mathrm{P}}\right)$ as projected from mean May/June temperature from high resolution climate data $\left(T_{\text {sim_high }}\right)$. Dark colours indicate early melt out, early onset of growth and highest plant heights. The results are shown for the HadCM3-A2 scenario for the period 1961-1990, 2001-2030, 2031-2060 and 2061-2100. Only grid cells within the four selected biogeographic regions (Fig. 1) with an altitude of $>1500 \mathrm{~m}$ a.s.l. Note that for each time period, grid cells exceeding the observed temperature range were removed.

The projected increase in productivity is likely to have major impacts on alpine ecosystems. The altered environmental conditions will probably lead to changes in plant communities. It can be expected that many plant species will migrate to higher elevations as can already be observed (Grabherr et al., 1994; Walther et al., 2005). Therefore, competition may increase in the lower alpine belt by highly productive species (Callaway et al., 2002; Wipf et al., 2006) and plant diversity may increase in the higher alpine and nival belt (Walther et al., 2005). Our estimates indicate an increase in aboveground standing biomass. This finding may lead to the conclusion that ecosystems above tree line may become a carbon sink in the future. On the other hand, warmer temperatures and increased microbial activity will likely cause a loss of carbon from alpine soils (Hagedorn et al., 2009). Since a higher amount of carbon is stored in soils than in the aboveground biomass above tree line (Devi et al., 2008; Kammer et al., 2009) this indicates that alpine ecosystems may turn into carbon sources rather than sinks.

\subsection{Limitations and benefits of the modelling approach}

In our study, we made use of a unique dataset measuring the end of the snow covered period, the onset of growth, and vegetation height at altitudes of 1500-2500 m a.s.l. at 17 sites in the Swiss Alps. Our modelling approach allowed us to make a first quantitative assessment of future melt out, timing of plant growth and productivity, whereas most previous studies have been mostly qualitative. Our regression model approach is simple, and was based on a large scale and long-term monitoring dataset. The simulations of melt out, onset of growth and plant height with low resolution climate models corresponded well with observations (Fig. 3), which suggests that the models were robust.

For the low resolution climate projections, we used single point ground observations to scale up to a $16 \mathrm{~km}$ grid cell. This is especially problematic in Alpine regions with extreme differences in microclimate. However, the IMIS data that we were using were significantly correlated to low resolution satellite data (Fontana et al., 2008), which showed that the IMIS data were representative for melt out, growth onset and vegetation height on a larger scale.

Our results illustrate how alpine plant communities may respond to climate change. It is important to note that our projections only hold if future plant communities resemble those today. Our data cover a large spatial and ecological domain, thus represent a range of different species assemblages. Therefore, our data cover both short-term responses, i.e. how a given plant community may respond to climate change without changing the species composition, as well as long-term responses, i.e. assuming that the plant community composition will change over time. It is of course uncertain how future plant communities will look like. However, numerous studies have demonstrated that alpine species have already started to migrate upward in response to rising temperatures within the last decades (Grabherr et al., 1994; Keller et al., 2000; Walther et al., 2005), which supports our view of long-term plant community change. 
The relationships between environmental variables and plant communities are more complex than a model can realistically cope with. Jonas et al. (2008) demonstrated with the same data set that climate indices drive alpine plant growth in a complex network of specific effects. Therefore, it is unlikely that simple linear relationships from one driving variable describe future changes in plant growth in detail. The onset of the vegetation period depends on the depth of the snow-pack, on water availability and many other factors (e.g. Dunne et al., 2003; Rixen et al., 2010). Plant growth will furthermore be influenced by effects of $\mathrm{CO}_{2}$, nutrient availability, land-use and the effects of extreme events that may lead to non-linear responses. The large scatter in the relationship between plant height and temperatures demonstrates that productivity is probably driven by other important factors than only temperatures (Fig. 2, right panel). Recent dynamic vegetation models have addressed the complexity of plant growth by explicitly including processes such as photosynthesis, respiration and carbon allocation within the plants to roots, leaves, sapwood and heartwood (e.g. Krinner et al., 2005; Sitch et al., 2003; Smith et al., 2001). These models explicitly incorporate the effects of climatology on plant growth over time such as changing temperature, precipitation, incoming radiation and $\mathrm{CO}_{2}$. Wolf et al. (2008) adapted a dynamic vegetation model (LPJ-GUESS) for arctic shrubland vegetation. Several dynamic forest models have been applied to estimate shifts in tree line (e.g. Cairns, 2005; Lischke et al., 2002; Rupp et al., 2001). However, dynamic models for simulating different alpine plant communities considering biotic interactions among species are scarce (Humphries et al., 1996). As a result, the models available today can not yet provide projections for more complex relationships between alpine climate and plant growth generally and for larger areas. Therefore, we chose a simple but robust temperature variable as a predictor for snow melt timing and plant growth to provide a first step towards estimating snow cover, plant phenology and plant productivity in alpine regions under changed climatic conditions. We trust the general validity of our models also from the fact that at tree line, temperature is the major driving force limiting growth (Körner, 1998). This is e.g. demonstrated by the fact that even the European heat wave in 2003 accompanied by a record drought caused increased plant growth above 1200-1500 m a.s.l. Obviously, moisture was not limiting, and therefore plants primarily responded to changes in summer temperatures in high elevation ecosystems (Jolly et al., 2005).

The climate mapping and the downscaling of climate anomalies may be prone to errors, specifically when it comes to forecasting regional differences. We believe that the general trend of earlier melt out and onset of growth and increased growth and biomass are reliable, while our spatial projections to sub-regional scale may be less reliable in general.

\section{Conclusions and future research needs}

Our results represent the first quantitative and spatially explicit estimates of climate change impacts on melt out, growth onset and productivity in the Swiss Alps. Our results indicate that by the end of the century significant changes in the timing of melt out (6-26 days earlier), onset of growth (one week to one month earlier) and productivity are expected to occur. This may seem to represent a relatively small change. However, as the vegetation period in the Alps is very short, the preponed onset of growth may result almost in a doubling of the length of the vegetation period. Likewise, the projections of biomass production over a season resulted in changes up to two-fold, which represents a dramatic increase in productivity and which will alter the dynamics of alpine ecosystems considerably. Also, we expect changes in both ecosystem processes, such as carbon and nutrient cycling, as well as changes in potential of the vegetation to reduce or increase natural hazards, such as snow avalanches or mud slides.

We see several future research needs from our results. First, long-term monitoring datasets such as the one applied in the present study are rare. However, particularly for estimating potential impacts of climate change, the value of this kind of data is high. In order to develop appropriate models to estimate changes in snow cover and vegetation, to estimate parameters and for the validation of these models, data from field measurements and from long-term monitoring sites are necessary. Additionally for this kind of studies, improved climate scenarios, particularly for precipitation at higher resolution are helpful. This and the results from our study could help to develop and improve dynamic models for alpine vegetation and/or coupled dynamic vegetation-snowpack models. Next, we propose experimental tests for better disentangling the effect of other factors from the dominant spring temperature effect. Notably, the interplay of precipitation (with its importance on snow cover duration) and temperature need to be studied. Finally, we believe that the development of better dynamic models for alpine ecosystems will be beneficial for making improved projections under climate change.

Acknowledgements. Climate data were provided from the EUproject "ALARM" with support from Thomas Hickler, Paul Miller and Stefan Frontzek. Matthias Ulmer provided the high resolution maps.

Edited by: C. Spirig 


\section{References}

Abegg, B., Agrawala, S., Crick, F., and de Montfalcon, A.: Climate change impacts and adaptation in winter tourism, in: Climate change in the European Alps: adapting winter tourism and natural hazards management, Organization for Economic Cooperation and Development, Paris, 25-60, 2007.

Arctic Climate Impact Assessment (ACIA): Impacts of a Warming Arctic, Cambridge University Press, New York, 139 pp., 2004.

Bavay, M., Lehning, M., Jonas, T., and Lowe, H.: Simulations of future snow cover and discharge in Alpine headwater catchments, Hydrol. Process., 23, 95-108, doi:10.1002/hyp.7195, 2009.

Beniston, M., Keller, F., Koffi, B., and Goyette, S.: Estimates of snow accumulation and volume in the Swiss Alps under changing climatic conditions, Theor. Appl. Climatol., 76, 125-140, doi:10.1007/s00704-003-0016-5, 2003.

Beniston, M.: Mountain weather and climate: A general overview and a focus on climatic change in the Alps, Hydrobiologia, 562, 3-16, doi:10.1007/s10750-005-1802-0, 2006.

Brooker, R. W., Travis, J. M. J., Clark, E. J., and Dytham, C.: Modelling species' range shifts in a changing climate: The impacts of biotic interactions, dispersal distance and the rate of climate change, J. Theor. Biol., 245, 59-65, 2007.

Cairns, D. M.: Simulating carbon balance at treeline for krummholz and dwarf tree growth forms, Ecol. Model., 187, 314-328, doi:10.1016/j.ecolmodel.2005.01.041, 2005.

Callaway, R. M., Brooker, R. W., Choler, P., Kikvidze, Z., Lortie, C. J., Michalet, R., Paolini, L., Pugnaire, F. L., Newingham, B., Aschehoug, E. T., Armas, C., Kikodze, D., and Cook, B. J.: Positive interactions among alpine plants increase with stress, Nature, 417, 844-848, 2002.

Camarero, J. J. and Gutiérrez, E.: Pace and pattern of recent treeline dynamics response of ecotones to climatic variability in the Spanish Pyrenees, Climatic Change, 63, 181-200, 2004.

Devi, N., Hagedorn, F., Moiseev, P., Bugmann, H., Shiyatov, S., Mazepa, V., and Rigling, A.: Expanding forests and changing growth forms of Siberian larch at the Polar Urals treeline during the 20th century, Global Change Biol., 14, 1581-1591, 2008.

Dunne, J. A., Harte, J., and Taylor, K. J.: Subalpine meadow flowering phenology responses to climate change: Integrating experimental and gradient methods, Ecol. Monogr., 73, 69-86, 2003.

Euskirchen, E. S., McGuire, A. D., Kicklighter, D. W., Zhuang, Q., Clein, J. S., Dargaville, R. J., Dye, D. G., Kimball, J. S., McDonald, K. C., Melillo, J. M., Romanovsky, V. E., and Smith, N. V.: Importance of recent shifts in soil thermal dynamics on growing season length, productivity, and carbon sequestration in terrestrial high-latitude ecosystems, Global Change Biol., 12, 731-750, 2006.

Fischlin, A. and Gyalistras, D.: Assessing impacts of climatic change on forests in the Alps, ISI:A1997XL65100004, 19-37, 1997a.

Fischlin, A. and Gyalistras, D.: Assessing impacts of climatic change on forests in the Alps, Global Ecol. Biogeogr., 6, 19-37, $1997 b$.

Fontana, F., Rixen, C., Jonas, T., Aberegg, G., and Wunderle, S.: Alpine grassland phenology as seen in AVHRR, VEGETATION, and MODIS NDVI time series - a comparison with in situ measurements, Sensors, 8, 2833-2853, 2008.

Franke, R.: Smooth interpolation of scattered data by local thin plate splines, Comput. Math. Appl. , 8, 237-281, 1982.
Fronzek, S., and Jylhä, K.: Scenarios of climate change for Europe, in: Atlas of Biodiversity Risks - from Europe to the globe, from stories to maps, edited by: Settele, J., Penev, L., Georgiev, T., Grabaum, R., Grobelnik, V., Hammen, V., Klotz, S., and Kühn, I., Pensoft, Sofia, Moscow, 2009.

Gehrig-Fasel, J. A. G., Guisan, A., and Zimmermann, N. E.: Tree line shifts in the Swiss Alps: Climate change or land abandonment?, J. Veg. Sci., 18, 571-582, 2007.

Gordon, C., Cooper, C., Senior, C. A., Banks, H., Gregory, J. M., Johns, T. C., Mitchell, J. F. B., and Wood, R. A.: The simulation of SST, sea ice extents and ocean heat transports in a version of the Hadley Centre coupled model without flux adjustments, Clim. Dynam., 16, 147-168, 2000.

Grabherr, G., Gottfried, M., and Pauli, H.: Climate effects on mountain plants, Nature, 369, 448, 1994.

Guisan, A., Theurillat, J. P., and Kienast, F.: Predicting the potential distribution of plant species in an Alpine environment, J. Veg. Sci., 9, 65-74, 1998.

Guisan, A. and Theurillat, J.-P.: Assessing alpine plant vulnerability to climate change: a modeling perspective, Integrat. Ass. Studies, 1, 307-320, 2000.

Hagedorn, F., Martin, M., Rixen, C., Rusch, C., Bebi, P., Zürcher, A., Siegwolf, R., Wipf, S., Escape, C., Roy, J., and Hättenschwiler, S.: Short-term responses of ecosystem carbon fluxes to experimental soil warming at the Swiss alpine treeline, Biogeochemistry, 97, 7-19, 2009.

Hickler, T., Fronzek, S., Araujo, M. B., Schweiger, O., Thuiller, W., and Sykes, M. T.: An ecosystem model-based estimate of changes in water availability differs from water proxies that are commonly used in species distribution models, Global Ecol. Biogeogr., 18, 304-313, doi:10.1111/j.1466-8238.2009.00455.x, 2009.

Humphries, H. C., Coffin, D. P., and Lauenroth, W. K.: An individual-based model of alpine plant distributions, Ecol. Model., 84, 99-126, 1996.

Inouye, D. W.: The ecological and evolutionary significance of frost in the context of climate change, Ecol. Lett., 3, 457-463, 2000.

IPCC: Climate Change 2007: The Physical Science Basis, Contribution of Working Group I to the Fourth Assessment Report of the Intergovernmental Panel on Climate Change, edited by: Solomon, S., Qin, D., Manning, M., Chen, Z., Marquis, M., Averyt, K. B., Tignor, M., and Miller, H. L., Cambridge University Press, Cambridge, UK and New York, NY, USA, 996 pp., 2007.

Jasper, K., Calanca, P., Gyalistras, D., and Fuhrer, J.: Differential impacts of climate change on the hydrology of two alpine river basins, Clim. Res., 26, 113-129, 2004.

Jolly, W. M., Dobbertin, M., Zimmermann, N. E., and Reichstein, M.: Divergent vegetation growth responses to the 2003 heat wave in the Swiss Alps, Geophys. Res. Lett., 32, L18409, doi:10.1029/2005GL023252, 2005.

Jones, H. G., Pomeroy, J. W., Walker, D. A., and Hoham, R. W.: Snow ecology, Cambridge University Press, 2001.

Kammer, A., Hagedorn, F., Shevchenko, I., Leifeld, J., Guggenberger, G., Goryacheva, T., Rigling, A., and Moiseev, P.: Treeline shifts in the Ural mountains affect soil organic matter dynamics, Global Change Biol., 15, 1570-1583, 2009.

Keller, F., Kienast, F., and Beniston, M.: Evidence of response of vegetation to environmental change on high-elevation sites in the Swiss Alps, Reg. Environ. Change, 1, 70-77, 2000. 
Körner, C.: A re-assessment of high elevation treeline positions and their explanation, Oecologia, 115, 445-459, 1998.

Krinner, G., Viovy, N., de Noblet-Ducoudre, N., Ogee, J., Polcher, J., Friedlingstein, P., Ciais, P., Sitch, S., and Prentice, I. C.: A dynamic global vegetation model for studies of the coupled atmosphere-biosphere system, Global Biogeochem. Cy., 19, 44, Gb1015, doi:10.1029/2003gb002199, 2005.

Kullman, L.: Rapid recent range-margin rise of tree and shrub species in the Swedish Scandes, J. Ecol., 90, 68-77, 2002.

Laternser, M. and Schneebeli, M.: Long-term snow climate trends of the Swiss Alps (1931-99), Int. J. Climatol., 23, 733-750, doi:10.1002/joc.912, 2003.

Lischke, H., Guisan, A., Fischlin, A., and Bugmann, H.: Vegetation response to climate change in the Alps: modeling studies, in: Views from the Alps: Regional Perspective from Climate Change, edited by: Cebon, P., Dahinden, U., Davies, H. C., Imboden, D., and Jaeger, C. C., MIT Press, Cambridge, MA, 309350, 1998.

Magnusson, J., Jonas, T., Lopez-Moreno, I., and Lehning, M.: Snow cover response to climate change in a high alpine and half glaciated basin in Switzerland, Hydrol. Res., 41, 230-240, doi:10.2166/nh.2010.115, 2010.

Martin, M., Gavazov, K., Körner, C., Hättenschwiler, S., and Rixen, C.: Reduced early growing season freezing resistance in alpine treeline plants under elevated atmospheric $\mathrm{CO}_{2}$, Global Change Biol., 16, 1057-1070, 2010.

Marty, C.: Regime shift of snow days in Switzerland, Geophys. Res. Lett., 35, L12501, doi:10.1029/2008g1033998, 2008.

Menzel, A., Sparks, T., Estrella, N., Koch, E., Aasa, A., Ahas, R., Alm-Kubler, K., Bissolli, P., Braslavska, O., Briede, A., Chmielewski, F. M., Crepinsek, Y. C., Dahl, A., Defila, C., Donnelly, A., Filella, Y., Jatczak, F. M., Mestre, A., Nordli, O., Penuelas, J., Pirinen, P., Remisova, V., Scheifinger, H., Striz, M., Susnik, A., Van Vliet, A. J. H., Wielgolaski, F.-E., Zach, S., and Zust, A.: European phenological response to climate change matches the warming pattern, Global Change Biol., 12, 19691976, doi:10.1111/j.1365-2486.2006.01193.x., 2006.

Mindas, J., Skvarenia, J., Strelkova, J., and Priwitzer, T.: Influence of climatic changes on Norway spruce occurrence in the West Carpathians, J. Forest Sci., 46, 249-259, 2000.

Mitchell, T. D., Carter, T. R., Jones, P. D., Hulme, M., and New, M.: A comprehensive set of high-resolution grids of monthly climate for Europe and the globe: the observed record (19012000) and 16 scenarios (2001-2100), Tyndall Centre Working Paper, 30 pp., 2004.

Myneni, R. B., Keeling, C. D., Tucker, C. J., Asrar, G., and Nemani, R. R.: Increased plant growth in the northern high latitudes from 1981 to 1991, Nature, 386, 698-702, 1997.

Nakicenovic, N., Alcamo, J., Davis, G., De Vries, B., Fenhann, J., Gaffin, S., Gregory, K., Grübler, A., Jung, T. Y., Kram, T., La Rovere, E. L., Michaelis, L., Mori, S., Morita, T., Pepper, W., Pitcher, H., Price, L., Riahi, K., Roehrl, A., Rogner, H.-H., Sankovski, A., Schlesinger, M., Shukla, P., Smith, S., Swart, R. V., Van Rooijen, S., Victor, N., and Dadi, Z.: IPCC Special report on emission scenarios, edited by: Nakicenovic, N. and Swart, R., Cambridge University Press, Cambridge, 612 pp., 2000.
New, M., Hulme, M., and Jones, P.: Representing twentiethcentury space-time climate variability, Part II: Development of 19011996 monthly grids of terrestrial surface climate, J. Climate, 13, 2217-2238, 2000.

OcCC Konsortium: Klimaänderung und die Schweiz 2050 - Erwartete Auswirkungen auf Umwelt, Gesellschaft und Wirtschaft, OcCC/ProClim, Bern, 172, 2007.

Oerlemans, J.: Extracting a climate signal from 169 glacier records, Science, 308, 675-677, 2005.

Penuelas, J. and Boada, M.: A global change-induced biome shift in the Montseny mountains (NE Spain), Global Change Biol., 9, 131-140, 2003.

Rhyner, J., Bründl, M., Etter, H.-J., Steiniger, M., Stöckli, U., Stucki, T., Zimmerli, M., and Ammann, W.: Avalanche Warning Switzerland-Consequences of the Avalanche Winter 1999, Int. Snow Science Workshop, Penticton, Canada, 30 September to 3 October, 2002.

Rickebusch, S., Thuiller, W., Hickler, T., Araujo, M. B., Sykes, M. T., Schweiger, O., and Lafourcade, B.: Incorporating the effects of changes in vegetation functioning and $\mathrm{CO}_{2}$ on water availability in plant habitat models, Biol. Lett., 4, 556-559, doi:10.1098/rsbl.2008.0105, 2008.

Rixen, C., Schwoerer, C., and Wipf, S.: Winter climate change on different temporal scales in alpine dwarf shrubs, Polar Res., 29, 85-94, 2010.

Rupp, T. S., Chapin, F. S., and Starfield, A. M.: Modeling the influence of topographic barriers on treeline advance at the foresttundra ecotone in northwestern Alaska, Climatic Change, 48, 399-416, 2001.

Rutishauser, T., Luterbacher, J., Defila, C., Frank, D., and Wanner, H.: Swiss spring plant phenology 2007: Extremes, a multicentury perspective, and changes in temperature sensitivity, Geophys. Res. Lett., 35(5), L05703, doi:10.1029/2007g1032545, 2008.

Sanz-Elorza, M., Dana, E. D., Gonzalez, A., and Sobrino, E.: Changes in the high-mountain vegetation of the central Iberian peninsula as a probable sign of global warming, Ann. Bot., 92, 273-280, doi:10.1093/aob/mcg130, 2003.

Scherrer, S. C., Appenzeller, C., and Laternser, M.: Trends in Swiss alpine snow days - the role of local and large scale climate variability, Geophys. Res. Lett., 31, L13215, doi:10.1029/2004GL020255, 2004.

Schleip, C., Menzel, A., and Dose, V.: Norway spruce (Picea abies): Bayesian analysis of the relationship between temperature and bud burst, Agr. Forest Meteorol., 148, 631-643, doi:10.1016/j.agrformet.2007.11.008, 2008a.

Schleip, C., Rutishauser, T., Luterbacher, J., and Menzel, A.: Time series modeling and central European temperature impact assessment of phenological records over the last 250 years, J. Geophys. Res.-Biogeo., 113(13), G04026, doi:10.1029/2007jg000646, 2008b.

Shepard, D.: A two-dimensional interpolation function for irregularly-spaced data, Proceedings of the 1968 ACM National Conference, 517-524, doi:10.1145/800186.810616, 1968.

Shiyatov, S. G., Terent'ev, M. M., Fomin, V. V., and Zimmermann, N. E.: Altitudinal and horizontal shifts of the upper boundaries of open and closed forests in the Polar Urals in the 20th century, Russ. J. Ecol., 38, 223-227, 2007. 
Sitch, S., Smith, B., Prentice, I. C., Arneth, A., Bondeau, A., Cramer, W., Kaplans, J. O., Levis, S., Lucht, W., Sykes, M. T., Thonicke, K., and Venevsky, S.: Evaluation of ecosystem dynamics, plant geography and terrestrial carbon cycling in the LPJ dynamic global vegetation model, Global Change Biol., 9, 161$185,2003$.

Smith, B., Prentice, I. C., and Sykes, M.: Representation of vegetation dynamics in the modelling of terrestrial ecosystems: comparing two contrasting approaches within European climate space, Global Ecol. Biogegr., 10, 621-637, 2001.

Sparks, T. H., Jeffree, E. P., and Jeffree, C. E.: An examination of the relationship between flowering times and temperature at the national scale using long-term phenological records from the UK, Int. J. Biometeorol., 44, 82-87, 2000.

Sturm, M., Racine, C., and Tape, K.: Climate change - Increasing shrub abundance in the Arctic, Nature, 411, 546-547, 2001.

Tape, K., Sturm, M., and Racine, C.: The evidence for shrub expansion in Northern Alaska and the Pan-Arctic, Global Change Biol., 12, 686-702, doi:10.1111/j.1365-2486.2006.01128.x, 2006.

Theurillat, J. P. and Guisan, A.: Potential impact of climate change on vegetation in the European Alps: A review, Climatic Change, 50, 77-109, 2001.
Thuiller, W., Albert, C., Araujo, M. B., Berry, P. M., Cabeza, M., Guisan, A., Hickler, T., Midgely, G. F., Paterson, J., Schurr, F. M., Sykes, M. T., and Zimmermann, N. E.: Predicting global change impacts on plant species' distributions: Future challenges, Perspect. Plant Ecol., 9, 137-152, doi:10.1016/j.ppees.2007.09.004, 2008.

Walther, G. R., Beissner, S., and Burga, C. A.: Trends in the upward shift of alpine plants, J. Veg. Sci., 16, 541-548, 2005.

Washington, W. M., Weatherly, J. W., Meehl, G. A., Semtner, A. J., Bettge, T. W., Craig, A. P., Strand, W. G., Arblaster, J., Wayland, V. B., James, R., and Zhang, Y.: Parallel climate model (PCM) control and transient simulations, Clim. Dynam., 16, 755-774, 2000.

Wipf, S., Rixen, C., and Mulder, C. P. H.: Advanced snowmelt causes shift towards positive neighbour interactions in a subarctic tundra community, Global Change Biol., 12, 1496-1506, 2006.

Wolf, A., Callaghan, T. V., and Larson, K.: Future changes in vegetation and ecosystem function of the Barents Region, Climatic Change, 87, 51-73, doi:10.1007/s10584-007-9342-4, 2008.

Zimmermann, N. E. and Kienast, F.: Predictive mapping of alpine grasslands in Switzerland: species versus community approach, J. Veg. Sci., 10, 469-482, 1999. 